\title{
The Efficacy of Three Indigenous Plants (Tetrapleura tetraptera, Bridelia ferruginea and Azadirachta indica) as Plant Derived Molluscicides against Fresh Water Snails
}

\author{
Afolabi Olajide Joseph", Ojo Babatunde David and Simon-Oke lyabo Adepeju \\ Department of Biology, Federal University of Technology Akure, Nigeria
}

*Corresponding author: Afolabi Olajide Joseph, Department of Biology, Federal University of Technology Akure, Ondo State, Nigeria, Tel: 234-803-595-9391

\begin{abstract}
Schistosomiasis is a parasitic disease transmitted by fresh water snail infected with the Schistosoma parasites. The disease is endemic in many parts of Asia, Africa, and South America affecting people who are unable to avoid contact with water, either because of their profession or because of lack of reliable source of safe water for drinking, washing and bathing. The study focused on the molluscicidal activities of the oil extracts of Tetrapleura tetraptera, Bridelia ferruginea and Azadirachta indica on freshwater snails. The snails were collected from a stream at Ipogun village, which is about $14 \mathrm{~km}$ away from Akure. The collected snails were transferred into glass tank containing water in the laboratory, where they were fed with lettuce and left for 3-4 days to adjust to the laboratory conditions. The fruit, barks and leaves of $T$. tetraplura, $B$. ferruginea and $A$. indica respectively were air dried, pulverized into powder and the powders were soaked in $70 \%$ ethanol. The oils from the plant powders were extracted using Soxhlet machine and the bioassay was done at varying concentrations $(0.4$, $0.8,1.2,1.6$, and $2.0 \mathrm{~g} / \mathrm{ml})$. Among all the plant extracts, Tetrapleura tetraptera showed the highest molluscicidal activity $(100 \%)$ at $1.6 \mathrm{mg} / \mathrm{l}$ and $2.0 \mathrm{mg} / \mathrm{l}$ for 48 hours of exposure. Meanwhile, the lowest molluscicdal activity (10\%) was found in Azadirachta indica at 8 hours of exposure. One-way Analysis of Variance of the result shows that there is significant difference in the molluscicidal activities of the three plant extracts $(p<0.05)$. It was also observed that the potency of the extracts increases as the concentrations and time of exposure increase. The results of this study show that the three plant extracts maybe used as veritable means of controlling schistosomiasis and other trematode infections.
\end{abstract}

\section{Keywords}

Schistosomiasis, Botanicals, Molluscicides, Toxicity, Mortality

\section{Introduction}

Schistosomiasis is also known as bilharziasis or "snail fever", is a parasitic disease transmitted by fresh water snail infected with one of the five species of the parasite Schistosoma [1]. The schistosomes or blood flukes belong to the class Trematoda of the phylum Platyhelminthes. They are parasites of the blood stream of warm blooded vertebrates. The definitive hosts of the parasites are humans and affect about 200 million people worldwide and is considered one of the most serious pathogenic infections today [2]. The species which infect man are Schistosoma haematobium, $S$. mansoni, S. intercalatum and S. japonicum.

Schistosomiasis is found predominantly in tropics and sub-tropical climates. It ranks second only to malaria as the most occurring parasitic disease in the tropics [2]. It is one of the important parasitic zoonotic diseases transmitted by one or more species of the snail species Bulinus. The disease is endemic in many parts of Asia, Africa, and South America. In Nigeria, a good number of foci infections have been documented in various parts of the country including some communities in Akure where this study is conducted [3-7]. However, in developing countries, the true epidemiological picture appears difficult because of inadequate researches in this direction despite its relevance in planning and control in any locality. This problem is compounded by the poor habits of people in developing countries in visiting hospital, for treatment also, self-medication is still practiced as manifested by anti-helminthic abuse. 
The disease is common among the school aged children especially in communities that lack potable water [3]. Hence, the children are always instructed by their parents to get water for domestic consumption in the nearby streams and rivers. These children consequently swim in the river especially during the dry season when the weather is hot. The attitudes expose the children to snail infection and makes this age group the most vulnerable group to the disease.

Bulinus spp is a freshwater snail which is medically important because its function as intermediate host of the schistosomiasis. These snails are widespread in Africa including Nigeria, Madagascar and the Middle East. Bulinus has become fully established in the USA, but it is considered to represent a potentially serious threat as a pest, an invasive species which could negatively affect agriculture, natural ecosystems, human health or commerce [4]. Therefore, it has been suggested that this species be given top national quarantine significance in Nigeria.

Lots of efforts have been taken by scientists and researchers to control the transmission of schistosomiasis by attacking the snail intermediate host. This control can be in form of botanical or chemical applications. However, chemical molluscicides has been noted to degrade slowly in the environment and often attack non-target organisms such as fish [8]. The high cost and toxicity of synthetic molluscicides, has also stimulated renewal of interests in plant molluscicides [9]. Hence, botanical control as part of integrated snail control stands to be a better alternative to the chemical control. Use of plant molluscicides stand to be a better alternative to chemical control due to the fact that plant molluscicides are cheap, eco-friendly, nontoxic and leave no residue in the environment. Examples of such botanicals that are readily available in Nigeria include Azadirachta indica, Bridelia ferruginea and Tetrapleura tetraptera [10]. Azadirachta indica, Bridelia ferruginea and Tetrapleura tetraptera has many traditional/ medicinal uses mainly in the management of malaria, rheumatic pains, coughs, gonorrhoea, painful and irregular menstruation respectively. In this research, the efficacy of oil extract of Azadirachta indica, Bridelia ferruginea and Tetrapleura tetraptera as potential molluscicides were investigated.

\section{Materials and Methods}

\section{Plant collection and identification}

The plants used were Tetrapleura tetraptera, Bridelia ferruginea and Azadirachta indica. This three plants were gotten at Oja Oba market, located in Akure the State capital of Ondo. The plants were identified by a taxonomist in the Department of Biology, Federal University of Technology Akure, Nigeria.

\section{Oil extraction}

The fruits of Tetrapleura tetraptera, the bark of
Bridelia ferruginea and leaves of Azadirachta indica were washed, air dried for 7 days and pulverized using a grinding machine. The fine powder were thereafter put into separate air tight container, labeled and kept until when needed. Hundred grams (100 g) each of the pulverized materials was weighed into thimble and their oils were extracted using $78 \%$ ethanol. The oil extraction was done using Soxhlet extractor machine. Thereafter, the thimble was removed from the unit and the ethanol was recovered by redistilling the contents using rotary evaporator and then air dried to remove any trace of solvent. The oils were kept in labeled plastic bottles till when needed.

\section{Snail collection and identification}

Adult snails were collected from Aponmu stream, a fresh water body surrounded by rocks and vegetation in Ipogun village of the Ifedore Local Government Area of Ondo State, Nigeria $\left(7^{\circ} 19^{\prime} \mathrm{N} ; 5^{\circ} 05 \mathrm{E}\right)$. The village is 14 $\mathrm{km}$ away from Akure, the state capital. The snails were collected using scoop net and immediately transferred into a glass container containing water. In the laboratory the snail were transferred into $26 \mathrm{~cm} \times 17.5 \mathrm{~cm}$ rectangular glass tank containing water, fed with water lettuce and monitored closely in the glass container for 72 hours. This initial exposure period allowed the snails to acclimatize to the laboratory conditions.

\section{Bioassay}

Ten fresh water snails in 4 replicates including control were introduced into each glass tank containing $0.4,0.8,1.2,1.6$ and $2.0 \mathrm{mg} / \mathrm{l}$ of Tetrapleura tetraptera, Bridelia ferruginea and Azadirachta indica oil extracts. The snail mortality was recorded as at $8,16,24,32,40$ and 48 hours of exposure to the oil extracts.

\section{Statistical analysis}

Data obtained were subjected to One-way ANOVA and where there is significant differences the means were separated using New Duncan Multiple Range test at $p<0.05$. $\mathrm{LC}_{50}$ and $\mathrm{LC}_{90}$ were also calculated for the data. All analyses were done using statistical package for social sciences (SPSS) 20.0 version.

\section{Results}

\section{Molluscicidal activities of Tetrapleura tetraptera at different exposure time}

The molluscicidal activities of Tetrapleura tetraptera was expressed as adult snail mortality as shown in Table 1. The result shows that the oil extract exhibited varying degrees of mortality at different concentrations and time of exposure. Sixty percent snail mortality was recorded at $2.0 \mathrm{mg} / \mathrm{l}$ and $1.6 \mathrm{mg} / \mathrm{l}$ for 8 hours and 16 hours of exposure respectively. Similarly, $80 \%$ mortality was recorded at $1.6 \mathrm{mg} / \mathrm{l}$ for 24 hours, 32 hours, 40 hours and 48 hours of exposure respectively. Meanwhile, $100 \%$ mortality was only achieved at $1.2 \mathrm{mg} / \mathrm{l}$ 
Table 1: Molluscicidal activities of Tetrapleura tetraptera at different exposure time.

\begin{tabular}{|l|l|l|l|l|l|l|}
\hline \multicolumn{2}{|l}{ Exposure time (hrs) } \\
\hline $\begin{array}{l}\text { Treatment } \\
\text { (mg/l) }\end{array}$ & 8 & 16 & 24 & 32 & 40 & 48 \\
\hline Control & $0.00 \pm 0.00^{\mathrm{a}}$ & $0.00 \pm 0.00^{\mathrm{a}}$ & $0.00 \pm 0.00^{\mathrm{a}}$ & $0.00 \pm 0.00^{\mathrm{a}}$ & $0.00 \pm 0.00^{\mathrm{a}}$ & $0.00 \pm 0.00^{\mathrm{a}}$ \\
\hline 0.4 & $0.00 \pm 0.00^{\mathrm{a}}$ & $0.00 \pm 0.00^{\mathrm{a}}$ & $20.00 \pm 0.00^{\mathrm{b}}$ & $20.00 \pm 0.00^{\mathrm{b}}$ & $40.00 \pm 0.29^{\mathrm{b}}$ & $60.00 \pm 0.25^{\mathrm{b}}$ \\
\hline 0.8 & $10.00 \pm 0.00^{\mathrm{b}}$ & $20.00 \pm 0.29^{\mathrm{b}}$ & $40.00 \pm 0.29^{\mathrm{c}}$ & $40.00 \pm 0.29^{\mathrm{c}}$ & $60.00 \pm 0.25^{\mathrm{c}}$ & $80.00 \pm 0.00^{\mathrm{c}}$ \\
\hline 1.2 & $20.00 \pm 0.29^{\mathrm{b}}$ & $40.00 \pm 0.25^{\mathrm{c}}$ & $40.00 \pm 0.29^{\mathrm{c}}$ & $60.00 \pm 0.25^{\mathrm{d}}$ & $80.00 \pm 0.41^{\mathrm{d}}$ & $100.00 \pm 0.25^{\mathrm{d}}$ \\
\hline 1.6 & $40.00 \pm 0.29^{\mathrm{c}}$ & $60.00 \pm 0.25^{\mathrm{d}}$ & $80.00 \pm 0.00^{\mathrm{d}}$ & $80.00 \pm 0.25^{\mathrm{e}}$ & $80.00 \pm 0.29^{\mathrm{d}}$ & $100.00 \pm 0.00^{\mathrm{d}}$ \\
\hline 2.0 & $60.00 \pm 0.00^{\mathrm{d}}$ & $60.00 \pm 0.25^{\mathrm{d}}$ & $80.00 \pm 0.00^{\mathrm{d}}$ & $80.00 \pm 0.25^{\mathrm{e}}$ & $100.00 \pm 0.25^{\mathrm{e}}$ & $100.00 \pm 0.00^{\mathrm{d}}$ \\
\hline
\end{tabular}

Each value is a mean \pm standard error of four replicate. Means followed by the same letter along the column are significantly different $(P<0.05)$ using Duncan's New Multiple Range Test.

Table 2: Molluscicidal activities of Bridelia ferruginea at different exposure time.

\begin{tabular}{|l|l|l|l|l|l|l|}
\hline \multicolumn{2}{|l}{ Exposure time (hrs) } \\
\hline $\begin{array}{l}\text { Treatment } \\
\text { (mg/l) }\end{array}$ & 8 & 16 & 24 & 32 & 40 & 48 \\
\hline Control & $0.00 \pm 0.00^{\mathrm{a}}$ & $0.00 \pm 0.00^{\mathrm{a}}$ & $0.00 \pm 0.00^{\mathrm{a}}$ & $0.00 \pm 0.00^{\mathrm{a}}$ & $0.00 \pm 0.00^{\mathrm{a}}$ & $0.00 \pm 0.00^{\mathrm{a}}$ \\
\hline 0.4 & $0.00 \pm 0.00^{\mathrm{a}}$ & $10.00 \pm 0.00^{\mathrm{b}}$ & $20.00 \pm 0.28^{\mathrm{b}}$ & $40.00 \pm 0.00^{\mathrm{b}}$ & $40.00 \pm 0.28^{\mathrm{b}}$ & $40.00 \pm 0.25^{\mathrm{b}}$ \\
\hline 0.8 & $10.00 \pm 0.00^{\mathrm{b}}$ & $20.00 \pm 0.29^{\mathrm{c}}$ & $40.00 \pm 0.00^{\mathrm{bc}}$ & $40.00 \pm 0.29^{\mathrm{b}}$ & $50.00 \pm 0.29^{\mathrm{b}}$ & $60.00 \pm 0.48^{\mathrm{c}}$ \\
\hline 1.2 & $20.00 \pm 0.29^{\mathrm{b}}$ & $40.00 \pm 0.00^{\mathrm{d}}$ & $40.00 \pm 0.25^{\mathrm{c}}$ & $50.00 \pm 0.29^{\mathrm{b}}$ & $70.00 \pm 0.25^{\mathrm{c}}$ & $70.00 \pm 0.25^{\mathrm{c}}$ \\
\hline 1.6 & $30.00 \pm 0.25^{\mathrm{bc}}$ & $40.00 \pm 0.29^{\mathrm{d}}$ & $60.00 \pm 0.57^{\mathrm{d}}$ & $70.00 \pm 0.00^{\mathrm{c}}$ & $80.00 \pm 0.00^{\mathrm{c}}$ & $90.00 \pm 0.29^{\mathrm{d}}$ \\
\hline 2.0 & $40.00 \pm 0.25^{\mathrm{c}}$ & $50.00 \pm 0.00^{\mathrm{d}}$ & $80.00 \pm 0.00^{\mathrm{e}}$ & $90.00 \pm 0.00^{\mathrm{d}}$ & $100.00 \pm 0.00^{\mathrm{d}}$ & $100.00 \pm 0.00^{\mathrm{e}}$ \\
\hline
\end{tabular}

Each value is a mean \pm standard error of four replicate. Means followed by the same letter along the column are significantly different $(P<0.05)$ using Duncan's New Multiple Range Test.

Table 3: Molluscicidal activities of Azadirachta indica at different concentrations and time.

\begin{tabular}{|l|l|l|l|l|l|l|}
\hline \multicolumn{2}{|l|}{ Exposure time (hrs) } \\
\hline $\begin{array}{l}\text { Treatment } \\
\text { (mg/l) }\end{array}$ & 8 & 16 & 24 & 32 & 40 & 48 \\
\hline Control & $0.00 \pm 0.00^{\mathrm{a}}$ & $0.00 \pm 0.00^{\mathrm{a}}$ & $0.00 \pm 0.00^{\mathrm{a}}$ & $0.00 \pm 0.00^{\mathrm{a}}$ & $0.00 \pm 0.00^{\mathrm{a}}$ & $0.00 \pm 0.00^{\mathrm{a}}$ \\
\hline 0.4 & $0.00 \pm 0.00^{\mathrm{a}}$ & $0.00 \pm 0.00^{\mathrm{a}}$ & $0.00 \pm 0.00^{\mathrm{a}}$ & $0.00 \pm 0.00^{\mathrm{a}}$ & $10.00 \pm 0.00^{\mathrm{b}}$ & $20.00 \pm 0.00^{\mathrm{b}}$ \\
\hline 0.8 & $0.00 \pm 0.00^{\mathrm{a}}$ & $0.00 \pm 0.00^{\mathrm{a}}$ & $10.00 \pm 0.25^{\mathrm{b}}$ & $10.00 \pm 0.25^{\mathrm{b}}$ & $10.00 \pm 0.25^{\mathrm{b}}$ & $20.00 \pm 0.55^{\mathrm{b}}$ \\
\hline 1.2 & $0.00 \pm 0.00^{\mathrm{a}}$ & $10.00 \pm 0.22^{\mathrm{b}}$ & $10.00 \pm 0.00^{\mathrm{b}}$ & $20.00 \pm 0.31^{\mathrm{c}}$ & $20.00 \pm 0.31^{\mathrm{b}}$ & $30.00 \pm 0.41^{\mathrm{c}}$ \\
\hline 1.6 & $10.00 \pm 0.28^{\mathrm{b}}$ & $10.00 \pm 0.23^{\mathrm{b}}$ & $20.00 \pm 0.15^{\mathrm{c}}$ & $20.00 \pm 0.25^{\mathrm{c}}$ & $20.00 \pm 0.45^{\mathrm{b}}$ & $40.00 \pm 0.77^{\mathrm{d}}$ \\
\hline 2.0 & $10.00 \pm 0.21^{\mathrm{b}}$ & $20.00 \pm 0.56^{\mathrm{c}}$ & $30.00 \pm 0.15^{\mathrm{d}}$ & $30.00 \pm 0.63^{\mathrm{d}}$ & $40.00 \pm 0.48^{\mathrm{c}}$ & $50.00 \pm 0.85^{\mathrm{e}}$ \\
\hline
\end{tabular}

Each value is a mean \pm standard error of four replicate. Means followed by the same letter along the column are significantly different $(P<0.05)$ using Duncan's New Multiple Range Test.

for 48 hours and $2.0 \mathrm{mg} / \mathrm{l}$ for 40 hours respectively. In contrast, no mortality was observed for the control experiment at all hours of exposure and $0.4 \mathrm{mg} / \mathrm{l}$ concentration at 8 hours and 16 hours respectively (Table 1 ).

\section{Molluscicidal activities of Bridelia ferruginea at different exposure}

The snail mortality when exposed to increasing concentrations of Bridelia ferruginea oil extract was presented in Table 2. The result reveals that mortality increases as concentration and time of exposure increased. It was observed that none of the snail died in the control experiment and when they were exposed to $0.4 \mathrm{mg} / \mathrm{l}$ of the oil extract for 8 hours. Meanwhile, as the hours of exposure increased from 16 hours to 48 hours, mortality also increased from $10 \%$ to $40 \%$. But for $0.8 \mathrm{mg} / \mathrm{l}, 10 \%$ mortality was recorded at 8 hours of exposure and this mortality also increased as the time of exposure also increased from 8 hours to 48 hours. Meanwhile, a higher mortality (60\%) was recorded at $0.8 \mathrm{mg} / \mathrm{l}$ for 48 hours of exposure compare to $40 \%$ mortality recorded at $0.4 \mathrm{mg} / \mathrm{l}$ for the same hour of exposure (48 hours). These significant increases were noted for other concentrations tested. Meanwhile, the oil extract only achieved $100 \%$ mortality at $2.0 \mathrm{mg} / \mathrm{l}$ for 40 hours (Table 2 ). 


\section{Molluscicidal activities of Azadirachta indica at} different concentrations and time

The molluscicidal activities of Azadirachta indica as presented in Table 3 show that no mortality was recorded for the control experiment and when the snails were exposed to $0.4 \mathrm{mg} / \mathrm{l}$ for $8-32$ hours, 0.8 $\mathrm{mg} / \mathrm{l}$ for $8-16$ hours and $1.2 \mathrm{mg} / \mathrm{l}$ for 8 hours. The first mortality (40\%) recorded for Azadirachta indica oil extract during the bioassay was recorded at $0.4 \mathrm{mg} / \mathrm{l}$ for 48 hours of exposure. Meanwhile, despite increased in concentration and time of exposure the highest mortality recorded by this oil extract is $50 \%$ which was achieved at $2.0 \mathrm{mg} / \mathrm{l}$ for 48 hours. This implies that the oil extract could not achieve $100 \%$ mortality even at the highest concentration tested. This infers that the oil extract of the plant has a weak molluscicidal activity against the snails.

\section{Toxicity of the plant extracts}

Lethal concentration $\left(\mathrm{LC}_{50}\right.$ and $\left.\mathrm{LC}_{90}\right)$ that is the concentration that will kill half and $90 \%$ of the population of the fresh water snails was also considered to test the toxicity of the oil extracts on the snail population. $\mathrm{LC}_{50}$ is one way to measure the shorttime poisoning (acute toxicity) of a toxic material. In general the smaller the $\mathrm{LC}_{50}$ value the more toxic the material and vice versa. It was observed from Table 4 that Tetrapleura tetraptera with $\mathrm{LC}_{50}$ and $\mathrm{LC}_{90}$ of 0.43 $\mathrm{mg} / \mathrm{l}$ and $0.86 \mathrm{mg} / \mathrm{l}$ respectively was the most potent of the three extracts. This was closely followed by Bridelia ferruginea with $\mathrm{LC}_{50}$ and $\mathrm{LC}_{90}$ of $0.6 \mathrm{mg} / \mathrm{l}$ and $1.36 \mathrm{mg} / \mathrm{l}$ respectively. In contrast, the least toxicity was observed in Azadirachta indica with $\mathrm{LC}_{50}$ and $\mathrm{LC}_{90}$ of $1.93 \mathrm{mg} / \mathrm{l}$ and $3.67 \mathrm{mg} / \mathrm{I}$ respectively. Similarly One-way ANOVA shows that there is significant difference in the toxicity of the extracts at different concentrations $(p<0.05)$.

\section{Discussions}

This study reveals that the ethanoic oil extract of $T$. tetraplura and $B$. ferruguinea are highly toxic to fresh water snails that serve as intermediate host of schistosomiasis but, the oil extracts of $A$. indica was fairly toxic to the fresh water snails because at the highest concentration only $50 \%$ mortality was recorded for all replicates. The toxicity of $T$. tetraptera was most active at the last three concentrations $(1.2,1.6$ and 2.0 $\mathrm{mg} / \mathrm{l}$ ) at 48 hours of exposure where $100 \%$ mortality was observed. Lower concentrations ( 0.4 and $0.8 \mathrm{mg} / \mathrm{l}) \mathrm{did}$ not give $100 \%$ mortality which indicated that the snails were able to withstand the toxicity of the oil extract at lower concentrations. Reduced mortality observed at lower concentrations may be due to low concentration and the time frame, while higher mortality observed at higher concentrations within short time can probably be linked to the oil toxicity and concentration itself. The high toxicity shown by $T$. tetraplura as shown by its low $\mathrm{LC}_{50}(0.43 \mathrm{mg} / \mathrm{l}$ and $0.86 \mathrm{mg} / \mathrm{l})$ and $\mathrm{LC}_{90}(0.6 \mathrm{mg} / \mathrm{l}$ and $1.36 \mathrm{mg} / \mathrm{l}$ ) has been attributed to the presence of tannins, saponins and flavonoids in its fruit and barks [11]. The molluscicidal activity of $T$. tetraplura has also

Table 4: Molluscicidal activity of the oil extracts of Tetrapleura tetraptera, Bridelia ferruginea and Azadirachta indica.

\begin{tabular}{|c|c|c|c|c|}
\hline Treatment (mg/l) & $\%$ Mortality + S.E & $\mathrm{LC}_{50}(\mathrm{mg} / \mathrm{l})+\mathrm{S} . \mathrm{E}$ & $L C_{90}(m g / l)+S . E$ & $P$-value \\
\hline \multicolumn{5}{|c|}{ Tetrapleura tetraptera } \\
\hline Control & $0.00 \pm 0.00$ & & & \\
\hline 0.4 & $30.42 \pm 0.13$ & & & \\
\hline 0.8 & $47.50 \pm 0.18$ & $0.43 \pm 0.41$ & $0.86 \pm 0.65$ & 0.03 \\
\hline 1.2 & $65.00 \pm 0.29$ & & & \\
\hline 1.6 & $73.75 \pm 0.19$ & & & \\
\hline 2.0 & $80.83 \pm 0.13$ & & & \\
\hline \multicolumn{5}{|l|}{ Bridelia ferruginea } \\
\hline Control & $0.00 \pm 0.00$ & & & \\
\hline 0.4 & $31.25 \pm 0.14$ & & & \\
\hline 0.8 & $40.42 \pm 0.23$ & $0.61 \pm 0.55$ & $1.36 \pm 0.87$ & 0.01 \\
\hline 1.2 & $54.58 \pm 0.22$ & & & \\
\hline 1.6 & $65.83 \pm 0.23$ & & & \\
\hline 2.0 & $78.33 \pm 0.04$ & & & \\
\hline \multicolumn{5}{|l|}{ Azadirachta indica } \\
\hline Control & $0.00 \pm 0.00$ & & & \\
\hline 0.4 & $5.00 \pm 0.00$ & & & \\
\hline 0.8 & $7.92 \pm 0.13$ & $1.93 \pm 3.09$ & $3.67 \pm 9.01$ & 0.00 \\
\hline 1.2 & $13.75 \pm 0.19$ & & & \\
\hline 1.6 & $19.58 \pm 0.19$ & & & \\
\hline 2.0 & $28.75 \pm 0.14$ & & & \\
\hline
\end{tabular}


been reported by the research of Oniya, et al. [5] who reported $100 \%$ adult snail mortality at $1.2 \mathrm{mg} / \mathrm{l}$ and 1.6 $\mathrm{mg} / \mathrm{l}$ at 48 hours of exposure.

The toxicity of Bridelia ferruginea against the freshwater snails as established by this research shows that the oil extract achieved $100 \%$ mortality at $2.0 \mathrm{mg} / \mathrm{l}$ for 40 hours of exposure. This molluscicidal activity has been associated with the presence of tannins on the leaves and barks of the plant [11,12]. Apart from this molluscicidal activity, boiled extract of Bridelia ferruginea has been reported to have antimicrobial effect on Gram +ve bacteria such as Sarcinalutea and Staphylococcus aureus [10]. In contrary, among the three plants used Azadirachta indica showed the least toxicity as noted from its relatively high $\mathrm{LC}_{50}(1.93 \mathrm{mg} / \mathrm{l})$ and $\mathrm{LC}_{90}(3.67 \mathrm{mg} / \mathrm{l})$. It was noted that even at the highest tested concentration $(2.0 \mathrm{mg} / \mathrm{l})$ the oil extract of $A$. indica could only achieve $50 \%$ mortality. Generally, it was noted that the toxicity of the all the extracts increases as the concentration and time of exposure increase. Other botanicals in which molluscicides have been confirmed include Acacia concinna in Gwalior, India [13]; solvent extracts of Solanum spp in Egypt [14]; ethanol extracts of seeds of Madlinca indica, Phytolacca accinosa, Thevetia peruviana, Alstonia scholaris, Euphorbia pulcherrima and Euphorbia hirta in Uttar Pradesh India [15]; Aqueous suspension Ammi majus flowers and leaves in Cairo, Egypt [16].

\section{Conclusion}

It is clear that fresh water snail causes enormous problems in endemic areas and that inadequate control can lead to serious problems affecting inhabitants of such areas. Existing control measures are not enough to deal with emergence or outbreaks of diseases caused by fresh water snails. Therefore, continued research including using plants based products is important to produce botanical molluscicides that are cheap, less toxic and effective to control fresh water snail population. The intermediate hosts play an essential role in the parasite life cycle. Molluscicides are therefore very crucial for controlling schistosomiasis if appropriately used. This research shows that $T$. tetraptera and B. ferruginea could interrupt the cycle of the schistosome by its molluscicidal properties. For this reason the use of plant molluscicides may be one of the veritable means of controlling schistosomiasis and other trematode infections. In addition, endemic communities are likely to accept the use of local indigenous plants since they are familiar with their properties and growth characteristics.

\section{Acknowledgements}

The authors appreciate the contribution of $\mathrm{Dr}$ J.O. Akinneye of the Department of Biology, Federal University of Technology Akure, Nigeria for the identification of the plants. We also acknowledge Mrs E.T. Ojo of the Research Laboratory, Department of
Biology, Federal University of Technology Akure, Nigeria for the plant oil extraction.

\section{Authors' Contributions}

This work was carried out in collaboration among the authors. All authors read and approved the final manuscript before submission.

\section{References}

1. Brown DS (1994) Freshwater snails of Africa and their medical importance. Taylor and Francis, ISBN 0-7484-0026-5.

2. Chitsulo L, Engels D, Montresor A, Savioli L (2000) The global status of schistosomiasis and its control. Acta Tropica 77: 41-51.

3. Akinneye JO, Fasidi MM, Afolabi OJ, Adesina FP (2018) Prevalence of schistosomiasis among secondary school students in Ifedore Local Government, Ondo State, Nigeria. Int J Trop Dis 1: 004.

4. Adema CM, Bayne CJ, Bridger JM, Knight M, Loker ES, et al. (2012) Fresh water snails and the diseases they transmit. PubMed: 51: 65-69.

5. Oniya MO, Adigun DO, Afolabi OJ (2013) Evaluation of the molluscicidal activity of oil extracts of Tetrapleura tetraptera and Xylopia aethiopica on Bulinus globosus (Mollusca; Planorbidae). Nigerian Journal of Parasitology 34: 21-24.

6. Ukoli FMA (1990) Introduction to parasitology in Tropical Africa. John Wiley and Sons Ltd, Chichester.

7. Agbolade OM, Akinboye DO, Fajebe OT, Abolade OM, Adebambo AA (2004) Human urinary schistosomiasis transmission foci and period in an endemic town of ljebu North, Southwest Nigeria. Trop Biomed 21: 15-22.

8. Rug M, Ruppel A (2000) Toxic activities of chemicals on snail hosts and non-target organisms. Tropical Medicine and International Health 5: 423-430.

9. Massoud AM, Habib FS (2003) The effects of myrrh (Commiphora molmol) on the infected snails of the Schistosoma species and their egg masses: Effect on shedding of cercariae and on snail fecundity. J Egypt Soc Parasitol 33: 585-596.

10. Kurt H, Andrew M, Karine N, Jean-Luc W (2000) The potential of African plants as a source of drugs. Institute de Pharmacognosie et Phytochimie, Universitie de Lausanne, BEP, CH-1015 Lausanne, Switzerland. 4: 973-1010.

11. Adesina SK, Adewunmi CO, Marquis VO (1980)Phytochemical investigation of the molluscicidal properties of Tetrapleura tetraptera. Journal of African Medicinal Plants 3: 7-15.

12. Afolayan M, Radhakrishnan SvS, Olayinka TA, Oluwole BF, Samir AR (2018) Chemical and biological studies on Bridelia ferruginea grown in Nigeria. Nat Prod Res 19: 1-5.

13. Sukumaran D, Parashar BD, Rao KM (2002) Evaluation of some plant molluscicides against a freshwater snail Lymnaea luteola, the vector of animal schistosomiasis. Pharmaceutical Biology 40: 450-455.

14. Gehad TE, Rawia AZ, Eman TE (2009) Molluscicidal activity of some Solanum species extracts against the snail Biomphalaria alexandrina. Journal of Parasitology Research 5.

15. Singh SK, Yadav RP, Singh A (2010) Molluscicides from some common medicinal plants of eastern Uttar Pradesh, India. J Appl Toxicol 30: 1-7.

16. Rawi SM, Al-Hazmi M, Seif- Al Nassr F (2011) Comparative study of molluscicidal activity of some plants extracts on the snail vector of Schistosoma mansoni, Biomphalaria alexandrina. International Journal of Zoological Research 7: 169-189. 